\title{
Lumbar Spine MR Imaging : Relation Between Edema Like Signal in the Posterior Soft-Tissue and Body Mass Index
}

\author{
Sameeah Abdulrahman Rashid* ${ }^{\star}$ Mohamed Muyaser Naif** , Hadeel Mohamed Farooq ${ }^{\star * \star}$ \\ *Department of Surgery, College of Medicine, Hawler Medical University, Erbil//raq, \\ **Department of Surgey-Radiology Unit, College of Medicine,University of Nineveh ,Mosul//raq \\ , ${ }^{* * *}$ Department of Radiology, College of Medicine , University of Mosul, Mosul//raq \\ Correspondence: sameeah.abdulrahman@hmu.edu.krd
}

(Ann Coll Med Mosul 2021; 43 (1):42-47).

Received: $25^{\text {th }}$ Dece. 2020; Accepted: $8^{\text {th }}$ Febr. 2021.

\section{ABSTRACT}

Background: It is not uncommon to encounter edema like signal within the soft tissue of the posterior lumbar region in MRI of the spine; however the exact explanation of such edema is not established yet.

Objectives: To find out relationship between edema like lesion in the soft tissue of the posterior lumbar region on spine $\mathrm{MRI}$ with $\mathrm{BMI}$, age and gender.

Patients and Methods: Lumbar Spine MRI of 288 outpatients suspected to have disc disease ( 150 females and 138 males ) performed on 1.5 Tesla facility was evaluated. Subjects with systemic or local disease likely to produce edema were excluded to obtain healthier subjects. The scans were reviewed for presence, site, and degree of High T2 edema like signal within the posterior lumbar soft tissue. The subjects were divided into four subgroups according to BMI and two groups according to their age ( $\leq 50$ or $>50$ years old). The edema was scored from $0-5$ based on its length relative to vertebral-body height. Correlation between the presence and extent of edema was made with BMI, age and gender.

Results: Among the 288 cases, $116(40 \%)$ patients had lumbar soft tissue edema. Association was found between the degree of edema and BMI $(P=.001)$ and with age $(P=.041)$. The presence of edema was noticed to be significantly more among women $(P=.045)$, while the average level of edema epicenters was approximately similar ( $L 3.6$ and $L 4$ consequently, $\mathrm{P}=.58$ ).

Conclusion: There is a positive relationship between the frequency and extent of posterior lumbar soft tissue edema with BMI and age.

Keywords: BMI, Edema, Lumbar spine, MRI.

$$
\begin{aligned}
& \text { تصوير العمود الفقري القطني بالرنين المغناطيسي: العلاقة بين أشارة الوذمة } \\
& \text { في الأنسجة الرخوة الخلفية ومؤشر كتلة الجسم الرئم }
\end{aligned}
$$

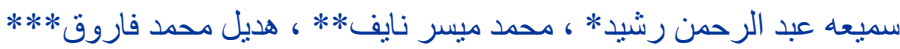

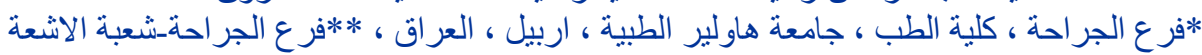

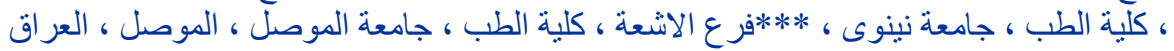

الغرض من الدراسة : اكتشاف العلاقة بين الوذمة الظاهرة فى الأنسجة الرخوة فى المنطقة الخلفية للعمود الفقرى القطنى بالرنين

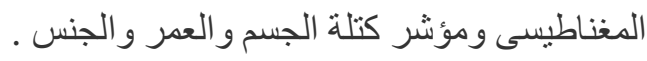

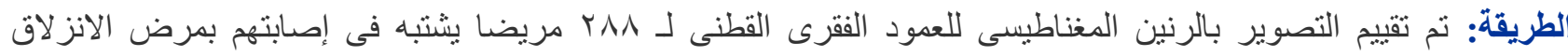

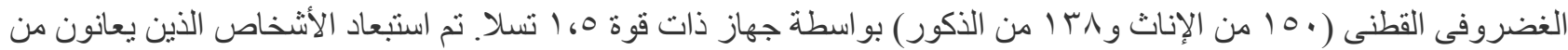

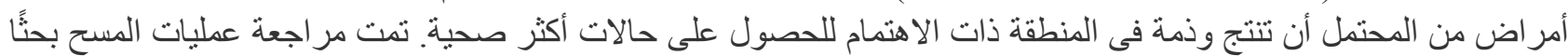

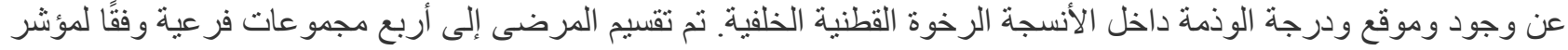

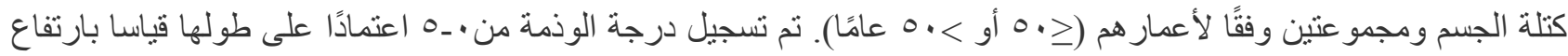

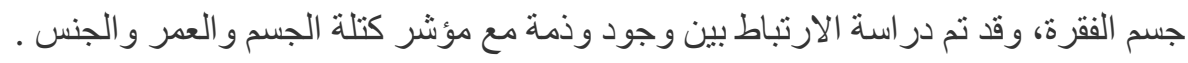




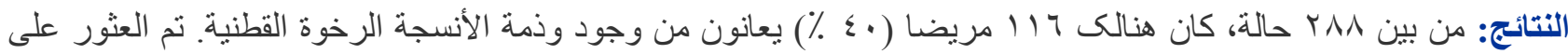

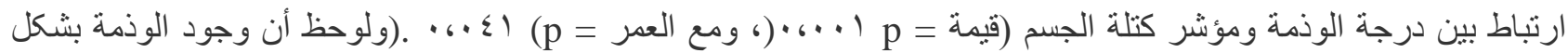

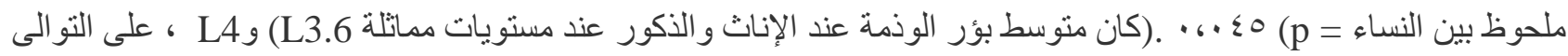

$$
\begin{aligned}
& \text {. ( } p=0.58 \text { ، } \\
& \text { الاستنتاج: هناك علاقة إيجابية بين مؤشر كتلة الجسم والعمر و الجنس مع تكر ار ومدى وذمة الأنسجة الرخوة القطنية الخلفية. } \\
& \text { الكلمات المفتاحية : مؤشر كتلة الجسم ، الوذمة ، العمود الفقري القطني ، الرنين المغناطبسي . }
\end{aligned}
$$

\section{INTRODUCTION}

$M$ $R$ imaging has been considered as the study of choice for investigating cases with low back pain, due to its high soft tissue resolution in neurological structure evaluation, multiplanar capability and lack of biohazard influence. ${ }^{1}$ A fluid or edema like signal could be noticed in many patients undergoing Lumbar Spine imaging within the adipose tissue of the posterior lumbar region, where it may be considered as incidental notice, some of them may display ill-defined or infiltrative pattern. ${ }^{2,3}$ On MRI , the notification of these fluid or edema could be assumed based on signal intensity, which is expected to be of high T2, low T1 and highlighted bright signal on T2 Fat Saturated sequences, as it appears in soft tissues else. $^{4}$

Although the definite explanation of such lumbar edema/fluid signal within the posterior adipose issue is not established yet, but studies are existing to determine the relation between the presence of such changes with body weight, and some had studied the relation of such findings with the various types of the degenerative changes \&/or spondylodiscitis in the lumbar region, ${ }^{2,3,5}$ however most of the studies did not consider the effect of systemic disorders which could produce such changes, like cardiac or renal diseases. Accordingly; The aim of the present study is to evaluate the relationship between the presence, and degree of such edema like signal, to BMI and other demographic features after exclusion of systemic and local disorders responsible for formation of edema in the soft tissue.

\section{MATERIALS AND METHODS}

This cross sectional study was performed in the radiology department of Rizgari Teaching Hospital/Erbil in the period from May to September 2019, cases that have sent to the MRI unit to undergo lumbar spine $\mathrm{MRI}$ for suspicion of having disc disease or for indication related to back pain \&/or radiculopathy were enrolled in the study sample, 348 consecutive Lumbar Spine MRI were reviewed and included in the study.
In order to obtain a more healthier subjects and avoid cases where their primary disease could produce edema in the tissue, several exclusion criteria were set , these included hospitalized/chronically bed ridden patients, subjects with trauma, spine surgery, lumbosacral tumor, known primary, diffuse skeletal metastasis, marked congenital spine anomaly or scoliosis , suspected or proved spondylodiscitis and patients known to have heart failure, renal or hepatic disease and cases with anasarca or diffuse tissue edema. Failure to obtain proper image quality or complete sequences was also considered in the exclusion list. If a patient had more than one lumbar spine MRI in the study period, only the 1st scan was enrolled in the study.

The final number of the patients enrolled in the study analysis was 288 cases, whose their BMI was recorded according to the standard formula after obtaining their weight and height .

The whole study group Lumbar spine MRI was performed on 1.5-T system (Magnetom Symphony; Siemens Medical Systems, Erlangon, Germany ) using spine coil. The routine department Lumbar spine protocol for cases suspected to have degenerative disc disease include, Sagittal T1, T2 and T2-Fat saturated sequences, selective axial T2 sequence through discs, as well as Myelo sequence in both sagittal and coronal. For the evaluation of the presumed edema in the posterior soft tissue of the lumbar spine, we depended mainly on fat-suppressed sagittal T2-weighted FSE sequence, as it highlights the required edema/fluid signal best. The sequences' parameters were as follows: echo-train length, 8; TR /TE for sagittal T2-weighted sequences, 3770 / 115; and TR/TE for sagittal T1-weighted sequences, 400/9. For all sequences we used section thickness of $4.0 \mathrm{~mm}$; intersection gap $=1.0 \mathrm{~mm}$; matrix $=\left(256^{\star} 320\right)$; and field of view of $\left(420^{\star} 420\right)=42 \mathrm{~cm}$.

By help of two radiologists, the MR images were assessed for the presence, size(extent), location and epicenter of the edematous signal. For the purpose of determining the degree or grade of the edema, we depended on the same scale system of (0-5) used by Shi et $\mathrm{al}^{2}$ depending on its length 
relative to height of vertebral body on sagittal plane. The scale was divided as the follows : Grade 0 for no edema, grade 1 for edema having a length of equal or less than the height of a single vertebra, grade 2 for edema length of equal or less than two vertebrae height but more than grade 1 , grade 3 for edema length of equal or less than three vertebrae height but more than grade 2, grade 4 for a length of edema equal or less than 4 vertebrae but more than grade 3 and finally grade 5 for any length more than grade 4 .

When multiple regions of edema is encountered, we used length summation to classify the degree of edema. The epicenter of edema was recorded from 1-5 according to the corresponding lumbar vertebral body levels or as , $1.5,2.5,3.5$ or 4.5 if the epicenter was at the level of inter-vertebral disc.

For the analysis of the data, four subgroups of patients were set according to their BMI and two subgroups according to their age $(<50$ year and $\geq 50$ year). The average degree of edema within each particular subgroup was calculated as the summation of the degree of edema of all patient within the particular divided by the number of patients in the same group .Chi-square tests were done for nominal dependent variables, to identify the presence or absence of edema in different $\mathrm{BMI}$, age , and gender groups. Non-parametric Mann-Whitney U-tests were used to determine the edema degree among different BMI, age and gender groups. To determine the relation between $\mathrm{BMI}$ and the degree of edema independent of age and gender, we used two-way parameteric ANOVA. For statistical significance, $P$ value was set as $<.05$.

The project was approved by the ethical committee of University of Mosule, College of Medicine.

\section{RESULT}

The final number of our study sample was 288 patients; 150 female and 138 male with age range of 1585 years; and mean age of 47.9(14.4 years). The mean BMI was 29.8 corresponding to grade 3 (range 18.4 for grade $1-53.3$ for grade 4 ). The demographic data of the study group is listed in Table 1.

Table 1 : Study population demographics

\begin{tabular}{|c|c|c|c|c|c|c|c|c|c|}
\hline \multirow{2}{*}{ Age (yr) } & \multicolumn{2}{|c|}{ BMI Grade 1} & \multicolumn{2}{|c|}{ BMI Grade 2} & \multicolumn{2}{|c|}{ BMI Grade 3} & \multicolumn{2}{|c|}{ BMI Grade 4} & \multirow[t]{2}{*}{ Total } \\
\hline & Female & Male & Female & Male & Female & Male & Female & Male & \\
\hline $\begin{array}{l}\leq 50 \\
>50\end{array}$ & $\begin{array}{l}2 \\
0\end{array}$ & $\begin{array}{l}3 \\
0\end{array}$ & $\begin{array}{l}18 \\
24\end{array}$ & $\begin{array}{l}11 \\
20\end{array}$ & $\begin{array}{l}16 \\
28\end{array}$ & $\begin{array}{l}16 \\
22\end{array}$ & $\begin{array}{l}29 \\
33\end{array}$ & $\begin{array}{l}40 \\
26\end{array}$ & $\begin{array}{l}135 \\
153\end{array}$ \\
\hline $\begin{array}{l}\text { Total } \\
(\%)\end{array}$ & $\begin{array}{l}2 \\
(40 \%)\end{array}$ & $\begin{array}{l}3 \\
(60 \%)\end{array}$ & $\begin{array}{l}42 \\
(57 \%)\end{array}$ & $\begin{array}{l}31 \\
(43 \%)\end{array}$ & $\begin{array}{l}44 \\
(53 \%)\end{array}$ & $\begin{array}{l}38 \\
(47 \%)\end{array}$ & $\begin{array}{l}62 \\
(48 \%)\end{array}$ & $\begin{array}{l}66 \\
(52 \%)\end{array}$ & \\
\hline $\begin{array}{l}\text { Final } \\
\text { total }\end{array}$ & 5 & & 73 & & 82 & & 128 & & 288 \\
\hline
\end{tabular}

Out of the 288 patient , 116 cases had lumbar edema(40\%). The frequency of patients who had lumbar edema and the degree of the edema both significantly raised with increasing $\mathrm{BMI}(\mathrm{P}=.001)$. The percentage of the cases with lumbar edema increased from from $20 \%$ in BMI grade 1 to $59.4 \%$ in BMI grade 4 , and the degree of lumbar edema also significantly increased in the higher BMI groups. The values of mean degree of edema in each BMI grades are shown in Table 2.

Table 2: The frequency and degree of lumbar edema according to BMI groups

\begin{tabular}{|l|l|l|l|l|l|}
\hline Finding & $\begin{array}{l}\text { BMI Grade 1 } \\
(<18.5)\end{array}$ & $\begin{array}{l}\text { BMI Grade 2 } \\
(18.5-24.9)\end{array}$ & $\begin{array}{l}\text { BMI Grade 3 } \\
(25-29.9)\end{array}$ & $\begin{array}{l}\text { BMI Grade 4 } \\
(\geq 30)\end{array}$ & P Value \\
\hline Degree of edema & $0.2(0.4)$ & $0.7(1.5)$ & $1.0(1.6)$ & $1.6(1.8)$ & .001 \\
\hline $\begin{array}{l}\text { Percentage of } \\
\text { patient with } \\
\text { edema }\end{array}$ & $20 \%$ & $24.2 \%$ & $32.5 \%$ & $59.4 \%$ & \\
\hline
\end{tabular}


The number and percentage of younger patients with edema were significantly lesser than the elder group and they had significantly lesser degree of edema, $(P=.003)$ and $(P=.041)$ respectively, as shown in table3.

Table 3: Distribution and degree of lumbar edema according to the age

\begin{tabular}{|l|l|l|l|}
\hline Finding & $\begin{array}{l}\leq 50 \text { Years } \\
\text { Old }\end{array}$ & $\begin{array}{l}>50 \\
\text { Years Old }\end{array}$ & P Value \\
\hline $\begin{array}{l}\text { Degree of } \\
\text { edema }\end{array}$ & $1.0(1.6)$ & $1.3(1.8)$ & .041 \\
\hline $\begin{array}{l}\text { Percentage } \\
\text { of patient } \\
\text { with edema }\end{array}$ & $32 \%$ & $51 \%$ & \\
\hline
\end{tabular}

With respect to gender variable, the frequency of lumbar edema and its degree were significantly more among female $(P=.045)$ (table 4); and in both gender groups ( male and female), there was a positive relationship between the lumbar edema degree and increased BMI regardless the age $(\mathrm{P}<.05)$

Table 4: the frequency distribution and degree of lumbar edema according to gender

\begin{tabular}{|l|l|l|l|}
\hline Finding & Female & Male & P Value \\
\hline $\begin{array}{l}\text { Degree of } \\
\text { edema }\end{array}$ & $1.1(1.7)$ & $1.1(1.6)$ & .045 \\
\hline $\begin{array}{l}\text { Percentage of } \\
\text { patient with } \\
\text { edema }\end{array}$ & $42 \%$ & $33 \%$ & \\
\hline
\end{tabular}

The mean length of edema in our study sample was $5.85(3.8) \mathrm{cm}$, ( ranging from $1.1-17 \mathrm{~cm}$ ) and the average vertical epicenters of edema among females (L3.6) and male(L4) was at almost the same levels $(P>.05)$, with L3-4 level being the commonest epicenter for the edema, accounting for $59 \%$.

Figure 1, shows two different patients with variable degree of posterior lumbar soft tissue edema

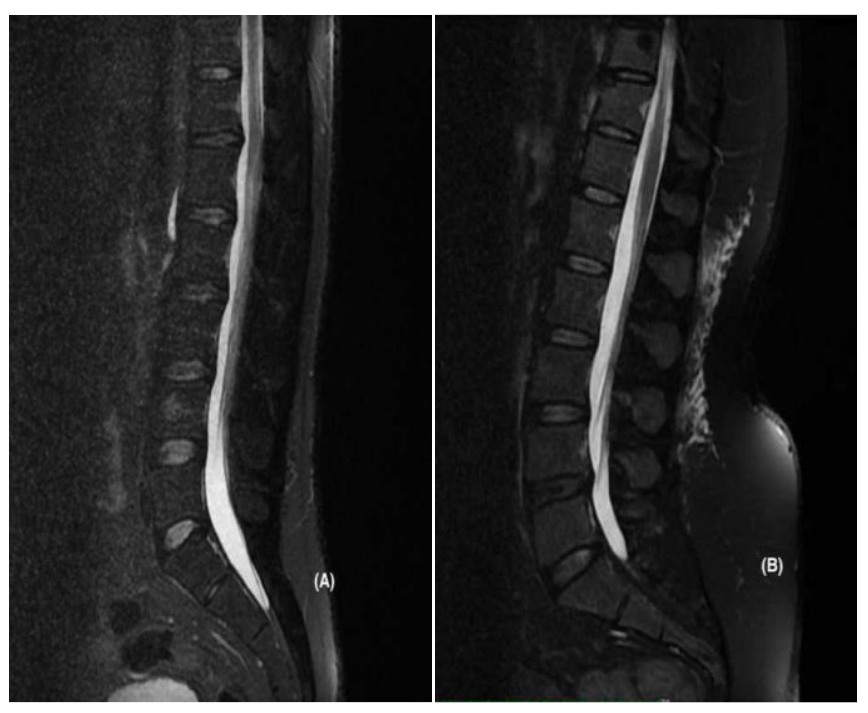

Figure 1 : Sagittal plane MRI T2 Fat Saturated Sequence for two different patients with variable grade of lumbar spine posterior soft tissue edema . (A) A young male patient with normal BMI , showing grade 0 edema (No edema), while (B) A 45 years old obese female patient, showing grade 4 edema in the posterior soft tissue of the lumbar region .

\section{DISCUSSION}

It is noticed that posterior lumbar soft tissue edema spread among high number of patients during lumbar spine MR imaging and most consider it as an incidental finding ${ }^{5}$ and there is debate on how to deal with incidental findings since it might result in over investigating patients, and the possibility of unneeded interventions , which may raise medical cost and the potential of worse results, ${ }^{6}$ accordingly many radiologists are overlooking this finding in their report .

The precise and definite nature of this soft tissue edema/fluid signal in the lumbar region is not clearly understood. Since the edema is observed within the soft tissue, it is dealt with as an extra-cellular fluid.

The commonest cause of extra-cellular fluid is fluid overload, ${ }^{7}$ but in the present study we tried to reduce the effect of fluid overload by selective 
exclusion of conditions responsible for fluid overload, hence other factors like microvascular dysfunction or abnormalities in the vessels pressure may be responsible.

The overall prevalence of lumbosacral soft tissue edema in our study sample was $40 \%$ which is compatible with Quattrocchi et al , ${ }^{8}$ who also reported the same prevalence. This prevalence is relatively high, and is most likely explained by the theory that back pain and lumbar degeneration could cause back soft tissue edema through reduction of lymphatic and venous drainage because of reduced physical activity . ${ }^{8}$

Considering the association between lumbar soft tissue edema and BMI, we have observed that posterior lumbar soft tissue edema is more frequently observed and is more severe among patients with higher BMI. This result is in line with the studies done by Shi et $\mathrm{al}^{2}{ }^{2}$ West et $\mathrm{al}^{,}{ }^{7}$ Quattrocchi et al , ${ }^{8}$ and Schwarz et al; ${ }^{9}$ however Shi et $\mathrm{al}^{2}$ depended on body weight rather than BMI in their study, and subjects' height was not taken into consideration which is an important factor in body built .

$\mathrm{Ga}$ Jin et $\mathrm{al}^{5}$ found that the degree of edema was not significantly correlated with BMI grade, but they noticed that edema was more common in obese patients.

Several mechanisms have been assumed to be responsible for edema in overweight and obese individual. Being obese would cause an increase in intra-abdominal pressure which may predispose to the formation of edema. ${ }^{7}$ Freeza et al have found that "for every $1 \mathrm{~kg} / \mathrm{mm} 2$ increase in BMI, there was on average a $0.07 \mathrm{~mm} \mathrm{Hg}$ increase in opening pressure" with subsequent elevation of inferior vena cava pressure,${ }^{10}$ and this may in turn lead to increase in fluid filtration into the interstitium because of high venous pressure. Additionally, obesity is found to be associated with expansion of the circulatory volume which might lead to elevation in intravascular pressure ;hence into the interstitium .11 Obesity could cause a reduction in lymphatic flow by a decrease in external intermittent compression on the lymphatic vessels which is related to the movement of the body and muscle contraction. ${ }^{2}$ Finally, in obese individual, there is elevation in the blood flow through peripheral capillary and increase in capillary permeability due to decrease response of cutaneous vasoconstriction to sympathetic activation . ${ }^{12}$

Concerning the relationship between posterior lumbar soft tissue edema and age, we observed that both the frequency and degree of edema was significantly more among older age subjects independent of BMI, and such result coincide with the result of Shi et $\mathrm{al}^{2}{ }^{2}$ West et $\mathrm{al}^{7}{ }^{7}$ and
Lakadamyali et $\mathrm{al}^{13}{ }^{13}$ although majority of the patients of BMI grade 3 and 4 were elder than lower BMI group.

Other causes might have attributed to the edema beside being overweight or obese. Elder subjects are possibly physically less active than younger individual which in turn have effect on muscle contraction and hence venous and lymphatic drainage .Microvascular dysfunction could occur even without obesity. Cell aging can induce lymphatic dysfunction by impairment of contractile function with consequent poor drainage of lymph. ${ }^{14}$ Aging also leads to increased permeability of the lymphatic vessels by its effect on the endothelium . ${ }^{14}$

$\mathrm{Lu}$ et $\mathrm{al}^{15}$ stated that in the lung "cigarette smoke increases endothelial cell permeability both in vitro and in vivo", but could the same principle be applied on soft tissue??. In the present study the association between cigarette smoking and lumbar soft tissue edema was not considered and the detail of the subjects' smoking history was not obtained.

Older individuals could have medical problems that might lead to development of soft tissue edema such as cardiac, hepatic or renal diseases more than younger ones, but in our study subjects known to have these entities were excluded. Accordingly; senility by itself could be a factor contributing to the development of soft tissue edema .

Regarding the association between lumbar edema and gender, we have found that the frequency and degree of lumbar edema was significantly more among female but to lesser extent of what have been noticed for BMI and age . Such finding agree with the result of Shi et $\mathrm{al}^{2}$ and Lakadamyali et al. ${ }^{13}$ As it is observed, edema occurs in the adipose layers of the lumbar region, and since female has more adipose tissue than male could in some way explain why female had more edema .

We acknowledge some limitations in the present study .

First, the exclusion of cases with systemic diseases that likely to produce edema, like cardiovascular, renal and hepatic diseases, was made based on the history (whether the patients known to have the disease or not ) and not based on clinical evaluation.

Second, cigarette smoking was not considered in our study, and we recommend further studies correlating the effect of Cigarette smoking and such edema like signal.

Third, some of our MRI examinations were done in Ramadan (fasting month in our country), and the subjects are likely to be dehydrated because of fasting, factor that we think may affect the results. 


\section{CONCLUSION}

Lumbar soft tissue edema are expected to be seen more commonly and more extensively in subjects with high BMI, higher age group and in female subjects even without having known systemic disorders or local disorder except for degenerative lumbar spine disease, but this should only be considered in the absence of other abnormal findings in the nearby structures like bones and muscles

The detection of such edema should not be ignored in the report by the radiologist, and the clinician should not underestimate its presence because as its observed, its correlation with BMI and age , and since MRI could detect edema at its early stages, such finding may trigger the clinician for a search to subclinical systemic entities responsible for edema production like renal or CVS disorders before it becomes symptomatic, as these disorders are more likely to be seen in high $\mathrm{BMI}$ and elderly groups .

Acknowledgment : None .

Financial Support: None .

Conflict of Interest : None.

\section{REFERENCES}

1.Humphreys SC, Eck JC, Hodges SD. Neuroimaging in low back pain. American Family Physician. 2002 Jun;65(11):2299-2306.

2.Shi H, Schweitzer ME, Carrino JA, Parker L. MR imaging of the lumbar spine: relation of posterior soft-tissue edema-like signal and body weight. Am J Roentgenol 2003; 180: 81-6.

3. Cooper M, Hacking JC, Dixon AK. Sacral edema: computed tomographic and anatomical observations. Clin Anat 1995;8:56-60

4. Schweitzer ME, Tran D, Deely DM, Hume EL. Medial collateral ligament injuries: evaluation of multiple signs, prevalence and location of associated bone bruises, and assessment with MR imaging. Radiology 1995;194:825-29.

5. Ga Jin Han, In Sook Lee, In Ho Han, Jung Sub Lee, Tae Yong Moon, Jong Woon Song, Posterior Lumbar-vertebra vertebra Subcutaneous Edema on Spine Imagining Resonance Images: What Is the Cause? J Korean Soc Radiol 2013;68(4):343350.http://dx.doi.org/10.3348/jksr.2013.68.4.343

6. Modic MT, Obuchowski NA, Ross JS, BrantZawadzki MN, Grooff PN, Mazanec DJ et al .Acute Low Back Pain and Radiculopathy: MR Imaging Findings and Their Prognostic Role and Effect on Outcome.Radiology 2005; 237(2): 597604.
7. West W, Brady-West D, West KP. A comparison of statistical associations between oedema in the lumbar fat on MRI, BMI and Back Fat Thickness (BFT). Heliyon. 2018;4(1):e500.

8. Quattrocchi CC1, Giona A, Di Martino A, Gaudino F, Mallio CA, Errante $Y$, et al .Lumbarvertebra vertebra subcutaneous edema and degenerative spinal disease in patients with low back pain: a retrospective MRI study .Musculoskelet Surg. 2015;99 (2):159-63

9.Schwarz-Nemec U, Friedrich KM, Arnoldner MA, Felix K, Schwraz MS, Weber M, et al. When an incidental $\mathrm{MRI}$ finding becomes a clinical issue. Wien Klin Wochenschr 2020; 132:27-34 .

10. Frezza EE, Shebani KO, Robertson J, Wachtel MS. Morbid Obesity Causes Chronic Increase of Intraabdominal Pressure. Dig Dis Sci 2007;52:1038-1041

https://doi.org/10.1007/s10620-006-9203-4

11. Lavie CJ, Messerli FH.Cardiovascular adaptation to obesity and hypertension. Chest 1986;90(2): 275-279.

12. Valensi $P$, L'Hermite $F$, Behar A, SandreBanon D, Cohen-Boulakia F, Attali JR. Extra cellular water and increase in capillary permeability to albumin in overweight women with swelling syndrome. Int $\mathrm{J}$ Obes Relat Metab Disord 2000;24:126-130

13. Lakadamyali $\mathrm{H}$, Tarhan NC, Ergun T, Cakir B, Agildere AM.STIR sequence for depiction of degenerative changes in posterior stabilizing elements in patients with lower back pain AJR Am J Roentgenol. 2008 Oct;191(4):973-9

14. Shang $\mathrm{T}$, Liang J, Kapron CM, Liu J. Pathophysiology of aged lymphatic vessels.Aging (Albany NY) 2019 Aug 28;11(16):6602-13. doi: 10.18632

15. Lu Q, Sakhatskyy P, Grinnell K, Newton J, Ortiz $M$, Wang $Y$ et al. Cigarette smoke causes lung vascular barrier dysfunction via oxidative stress-mediated inhibition of RhoA and focal adhesion kinase. Am J Physiol Lung Cell Mol Physiol 2011; 301: L847-57. 